\title{
Research on Teaching Reform of Costume CAD Course for Application-oriented Talents
}

\author{
Yuwei Guo \\ College of Information and Business \\ Zhongyuan University of Technology \\ Zhengzhou, China 450000
}

\author{
Zhijuan Tang \\ College of Information and Business \\ Zhongyuan University of Technology \\ Zhengzhou, China 450000
}

\begin{abstract}
This paper has proposed the requirements for application-oriented and interdisciplinary talents who have solid knowledge structure and strong comprehensive ability needed in the costume industry against such problems as teaching mode is simple, course contents setting and course evaluation system are not objective enough and so on that existing in the teaching methods of costume CAD course for the purpose of application-oriented cultivation based on employees' basic condition. And this paper has taken the requirements as reform policy, giving full consideration to the connection between costume CAD course teaching and various main courses for the major of costume design. Meanwhile, this paper has pointed out that adding of teaching hours for costume CAD course using diversified teaching methods may in favor of students' innovative thinking ability improvement and their professional comprehensive ability cultivation as well as the establishment of teaching evaluation system that is more objective and comprehensive.
\end{abstract}

Keywords-costum; costume design; CAD teaching; reform in depth

\section{INTRODUCTION}

The rapid development and extensive application since 1980s has aroused a new global industrial reform, and application level of information technology has been an important mark for measurement of the modernization level in a country or an area. Information technology has influenced the establishment and development of subjects in colleges and the reform in college education mode dramatically with its strong penetration along with the continuous development of information technology with computer as the core and its application in education in $21 \mathrm{st}$ century. Higher education has changed fundamentally in terms of purpose, contents, mode and methods as well as organization.

Costume CAD technology belongs to the aided design category of information technology application, and it is the product of computer technology and costume industry. It is one of the effective tools for costume industry to improve its quality and to strengthen innovative ability and market competitiveness, integrating the costume style design, costume structure design, costume industrial template design, grading and material layout, and reflecting the core of digital technology of costume industrial production. Costume CAD

Project No.: Project of Provincial Approval for Higher Education Reform in Henan 2014: 2014SJGLX369. is a course that is very professional with high requirement of practical operation in the study of college costume specialty for the purpose of enabling students to take full advantage of efficiency and convenience of information times to improve students' independent innovative ability of R\&D and production of costume design to the maximum extent, and to shorten the running-in period between students and the company, realizing the cultivation objective of college technology applied talents who are employment-oriented.

Based on relevant statistics, the costume CAD in western developed countries has popularized in costume enterprises basically, while the costume CAD technology application in Chinese costume industry has a low popularity rate in spite of its rapid development. China's "12th five-year" plan has proposed that the popularity rate of costume CAD shall achieve $80 \%$ by 2015 which is basically close to the level of developed countries. Therefore, the cultivation of costume CAD information technology talents in college is of significant meaning to realize sustainable development of China's costume industry. Facing the enormous social demands, and under the background of advocating cultivation of applied technology talents in college and increasing competition in employment of graduates, the proficiency of costume CAD information technology mastered by students majored in costume and their application level has determined graduates' competitive capacity in employment to some extent. To settle the problems exist in the teaching of costume CAD course in various costume colleges in Henan, this paper has put forward the teaching reform program of costume CAD course under the applied talent cultivation mode which is based on information technology.

\section{Teaching Status AnAlysis of Chinese CAD COURSE AT PRESENT}

Domestic costume CAD has developed for more than 40 years from introduction of foreign equipment to independent research and development, and the teaching contents of costume CAD has been updated along with the development of costume CAD. Even so, old teaching mode has revealed its various disadvantages as unable to meet current teaching requirements. The disadvantages mainly are as below: disconnection of course arrangement, lack of relation between the setting of costume CAD course and other 
specialized courses, resulting in students' incapability to digest what they have learned and losing interests in CAD course; disproportion between curriculum theory and practice hours due to control of traditional teaching mode, most teachers take class teaching as main mode, and practice hours is less than theory hours which accounts for over $60 \%$, resulting in the phenomenon that students understand theory but unable to operate; insufficient teaching resources as many of the text books are still old versions which cannot keep pace with the social development. Specifically, in current times of ever-changing costume information and technology, old theory cannot satisfy the information development, and students will derail with social and industrial development.

College of Information \& Business of Zhongyuan University of Technology has opened up costume CAD course and relevant practical segment for such majors as costume design \& engineering, costume \& apparel design, and the teaching mode that meets cultivation objectives of independent college has shaped gradually in the course of practice.

From the professional cultivation course for students of all levels specialized in costume engineering and costume design, and the investigation of employment and working condition of the graduates in past three years, we can see the obvious teaching effect of costume CAD course in our college, and students can be competent for their job quickly with outstanding performance.

From the teaching research of the teaching mode of costume CAD course in domestic clothing colleges to such courses of costume majors in our college, we can see that traditional teaching mode of costume CAD has been far from satisfaction of the demand by modern costume enterprise for high quality costume talents, and the disadvantages brought by traditional teaching mode has become increasingly obvious. The penetration and integration of teaching modes between costume CAD course and other courses are insufficient, and the optimization of system professional cultivation mode has been restrained constantly. Our college has taken the reform and innovation of teaching system and teaching mode of costume CAD course as the priority for the teaching reform in the practice of exploring applied talents cultivation, and abundant reform experience and excellent teaching effect has been obtained. However, along with the development of costume higher education and the demand for high-level technical talents by costume enterprises, more expectations for teaching reform of costume CAD course has been raised, which need to explore further for its maximum effect. While the cultivation mode of information technology talents may provide new thinking and methods for teaching practice of costume CAD course and the establishment and enforcement of teaching system for costume majors in accordance with standard.

\section{SPECIFIC REFORM FOR APPLIED TALENT Cultivation}

This research adopts the methods of integrating theory and practice in combination with the objectives of "cultivating the applied talents who are innovative and practical" by independent college. Firstly, conduct necessary summary and conclusion for the setting and reform of CAD course of costume specialty in colleges of the same kind, and make research and analysis of specific cases that have been conducted in teaching research and reform of costume CAD in our college starting from theory research; put forward new program for teaching research and reform against problems exist in the teaching of costume CAD course at present through analysis, and finally obtain the new mode for teaching reform of costume CAD course under the cultivation mode for information technological applied talents for generalization. Main contents for reform can be divided into 4 sections as below:

\section{A. Establish Comprehensive Course Mode for Costume $C A D$}

Classify the main curriculum of costume CAD courses that are connected closely, establish four course module (costume design module, structure design module, industrial plate making module, production process module) to support the comprehensive course mode of costume CAD jointly.

Modify the traditional separated teaching mode of costume $\mathrm{CAD}$ course, pay more attention to the relation and crossover between course systems, and establish new teaching system that is grading, multilevel, modularity and coordinating as a whole, enabling students to have necessary ability for adapting to information society.

\section{B. Deepen University-Enterprise Cooperation, Create Open and Interactive Teaching Atmosphere}

Participate in enterprise project, and form an interactive teaching mode with enterprise to optimize professional teaching resources of costume CAD, reform teaching methods from the perspective of both teachers and students to realize connection of professional course and industry based on the outstanding teaching features of professional, practical and applicable costume CAD courses. The basic curriculum theory shall adopt conventional teaching methods on campus, practice and training shall be accomplished by cooperation with enterprise both inside and outside college, set up network interaction platform between college and enterprise, to strengthen interaction between teacher and students in the process of updating teaching contents, avoiding teaching blindly in class, strengthening teaching hours of various practice and establishing an open and interactive teaching atmosphere.

\section{Characterization of Teaching System Construction}

Most of independent colleges take over teaching materials used by their parent universities, which is no good for individualized teaching and cultivation of applied talents in the course of using. As a result, the characteristic construction of costume CAD course is also extremely urgent. This reform has rewritten innovative teaching material with outstanding practicability, applicability and innovation, and established new knowledge system based teaching material written and published by project host in 
combination with the achievements obtained in the projects of teaching research and teaching reform on campus.

\section{Pay Attention to Occupational Orientation, and} Integrate Curriculum Evaluation System with CAXC Occupational Qualification Authentication by National Ministry of Education

CAXC is the project of National Computer Aided Technology Authentication initiated by Education and Management Information Center under National Ministry of Education in March 2010 (hereinafter referred to as "CAXC"). This project is designed for the skill course training and authentication for students majored in costume and in-service staff, and for cultivation of applied industrial and information-based technical talents adapt to the social development demand.

Innovation has been made for the curriculum evaluation system of this research, integrating enterprise training achievements and the CAXC qualification certificate into curriculum evaluation. Students whose curriculum test results has reached over 80 , and met the conditions required by CAXC project, may obtain relevant technical certificate of costume CAD issued by CAXA project, proving an excellent platform for students to hold a job, and strengthening their employment competence.

\section{ACHIEVEMENTS OF THIS CURRICULUM TEACHING REFORM}

The teaching reform of costume CAD course has providing us a perfect platform to evaluate students' learning in an objective and overall manner. What is positive is that relevant evaluation for students can be made in combination with costume manufactures with the questions set by enterprises in accordance with actual production demand in teaching of such projects as men' wear, women's wear and children' wear, and when the project learning has entered the final evaluation. Students shall finish the style design, material selection, structure design, and work out sample plate which can be used in actual production within required time using CAD, including a series operation of coding, material layout, process sheet making. In the end, evaluation shall be conducted by teachers and enterprises according to production reality, and manufacture may choose such style and sample plate which can be used in actual production from students' works to apply to production for obvious economic benefits, realizing win-win effect for the college and enterprise, rendering an excellent development for this evaluation system which shall be the most objective and persuasive.

The following are summarized based on the aforementioned reality:

- Realize curriculum setting closing to regional economic development and the curriculum system which takes information and technology application capability as a standard through this research and implementation.
- Realize the perfect connection between teaching system of costume CAD course and the social demand, establish the cooperative platform for colleges and local enterprises to cultivate talents.

- The teaching reform of costume CAD course has enabled us to improve our professional teaching from cultivation of basic skill of students majored in costume design to overall enhancement of students comprehensive application capability.

The in-depth combination between costume CAD and practical teaching may further deepen and develop continuously the cultivation of applied talents. Moreover, through practical experience of this research, we have obtained such talent cultivation program as to settle close teaching method and traditional teaching habits of paying attention to theory while ignoring practice, to combine theory with enterprise reality and combine college with social demand, as well as to integrate learning and employment skills, realizing "studies, occupation, production, employment and pioneering" as its main line, which enable students to truly realize transformation from knowledge to capability through simultaneous and alternative training between theory teaching and practical teaching, and to satisfy the requirements for cultivation of professional information and technical applied talents, realizing the establishment and promotion of cultivation mode for applied technical talents majored in costume in Henan.

\section{REFERENCES}

[1] Fan Juhong. Innovative Research on Teaching Methods of Costume Technology in College [J]. Beijing: Shangqing, 2008. (13)

[2] Huang Puquan. Modern Teaching Theory Courses. Beijing Educational Science Publishing House, 2003

[3] Li Yanglin. Discussion on Teaching Method of Costume CAD [J]. New Curriculum Research (Occupational Education). 2008 (09)

[4] Bai Xiaohong. Analysis of Teaching of Costume CAD [J]. Science \& Technology Information. 2008(10)

[5] Ni Jinfang. Discussion on Application-oriented Costume CAD Teaching in Vocational Colleges [J]. Academic Journal of Jilin Engineering Normal University. 2008(09) 